Manuscript ID

ZUMJ-2106-2260

DOI

10.21608/zumj.2021.80189.2260

ORIGINAL ARTICLE

\title{
ASSOCIATION OF FAT MASS AND OBESITY GENE (FTO) POLYMORPHISM WITH COVID-19 SEVERITY IN EGYPTIAN OBESE PATIENTS
}

Walaa M Sarhan*, Nahla Zidan **, Abeer El-Hawary***, Nagwan A. Ismail***, Vishruti Makani****, Hanim M. Abdel-nour *

*Medical Biochemistry and Molecular Biology Department, Faculty of Medicine, Zagazig University, Zagazig, Egypt

** Clinical Pathology Department, Faculty of Medicine, Zagazig University, Zagazig, Egypt.

*** Chest Department, Faculty of Medicine, Zagazig University, Zagazig, Egypt.

**** Process Development Scientist, KBI Biopharma, Durham, NC, US

\section{* Corresponding author:}

Walaa Mohamed Sarhan

Telephone:

00201002822129

Email:

walaasarhan@hotmail.com

Submit Date 2021-06-12

Revise Date 2021-06-15

Accept Date 2021-06-16

\section{1-ABSTRACT}

Background: Fat mass and obesity gene (FTO) polymorphism had linked with risks and health problems related to obesity in many studies and different population. Our study was designed to investigate association of FTO rs9939609 with COVID-19 severity and biochemical parameters such as serum triacylglycerol, cholesterol, transaminases and plasma glucose in obese Egyptian population.

Methods: TaqMan SNP Genotyping Assay of FTO gene rs9939609 (A < T) in a sum of 253 obese cases infected with COVID-19. Fasting samples of serum insulin, plasma glucose, lipid profile, as well as ALT and AST were measured. Evaluation of the association between COVID-19 severity and genotype distribution was done via logistic regression tests and Chi-square.

Results: The association of COVID-19 severity with genotype distribution was significant $(\chi 2=8.6 / \mathrm{P}=0.014)$ and odds ratio under dominant model $(\mathrm{OR}=1.86, \mathrm{P}=$ 0.029 and $95 \%$ C.I $=1.08-3.4)$ and recessive model $(\mathrm{OR}=2.95, \mathrm{P}=0.017$ and $95 \% \mathrm{C} . \mathrm{I}=$ 1.23-6.42) was increased. HDL-C levels in (AA) subjects $(\mathrm{P}=0.009)$ were significantly lower in comparison to (TT). Moreover, ALT levels in (AA) genotype subjects $(\mathrm{P}=$ 0.02 ) were significantly higher and persisted in accordance with correction of major confusing parameters as TAG and BMI, while aborted with conservative Bonferroni adjustment.

Conclusions: The current study displayed that Fat mass and obesity gene (FTO) rs9939609 is a risk factor for COVID-19 severity in obese individuals that may aid to understand the pathophysiology of the disease progression and highlighted that lipid metabolism may play a role in this association.

Keywords: Alt, COVID-19, FTO, HDL-c, Serum lipid, SNP, Obesity,

\section{INTRODUCTION}

A new beta coronavirus has been identified as the causing pathogen for Severe Acute Respiratory Syndrome Coronavirus 2 (SARS-CoV-2) [1]. The target organ for COVID-19 is the lung but affects other organs as well, causing multi-organ negative consequences [1,2].

Three stages have been observed in COVID19 patients, with reference to progression and extent: (i) "mild" which occurs in the vast majority of patients with minor symptoms and don't progress to severe disease; (ii) "moderate" these are hospitalized patients suffering from pneumonia on radiology accompanied with symptoms or laboratory lymphopenia or leukopenia; and (iii) "severe" who were admitted to the Intensive Care Unit due to systemic hyper-inflammatory status and ARDS and at risk of fatal outcome [3,4]. Regardless of various targeted and nontargeted method for management, no specific treatment has yet been proven effective in treating COVID-19.

Fat mass and obesity (FTO), or alphaketoglutarate-dependent dioxygenase, is a sample nominee gene for obesity with genome wide association evidence [5]. Many 
studies featured the association of this gene polymorphism with obesity in Egyptian population and others [6-11]. FTO variant rs9939609 (first intronic one) was specifically selected to current study because of its unique genotyping successful rate which is the highest compared to other risk single nucleotide polymorphisms related to obesity as well as its proved powerful genome wide association with obesity according to evidence-based studies [5]. Moreover, although this variant is not the true functional one, there is high probability that it is linked to disequilibrium with true functional variants in FTO gene or nearby genes [10]. Various studies showed that the obese patients were vulnerable to risk of having severe COVID19 [12-14].

Thus, current study was purposed for the investigation of FTO gene rs9939609 association with the degree of COVID-19 severity and its endophenotypes in Egyptian obese patients.

\section{Methods}

\subsection{Patients and Samples}

A total of random unrelated 253 COVID-19 patients were studied. They were recruited from Faculty of Medicine, Zagazig University, Egypt. The sample included 118 males and 135 females, of mean age \pm SD (41 \pm 15.3). Written informed consent was obtained from all participants, the study was approved by the research ethical committee of Faculty of Medicine, Zagazig University. The study was done according to The Code of Ethics of the World Medical Association (Declaration of Helsinki) for studies involving humans. Obesity was determined in accordance to anthropometric measures (body mass index $>30 \mathrm{~kg} / \mathrm{m}$ and waist circumference $\geq 80 \mathrm{~cm}$ ). They were sub grouped according to severity in reference to MOHP (Ministry Of Health \& Population) Protocol:

- 1st GROUP (Severe cases): with 124 patients, who were admitted to the ICU (Intensive Care Unit) due to COVID-19 serious consequences.

- 2nd GROUP (Mild cases): comprised 129 patients, the patients were considered as mild cases if they show symptoms with no radiological evidence for pneumonia with lymphopenia or leukopenia. And they were asked for home quarantine with follow up.

Detailed history taking, anthropometric measures, vital signs, and full medical evaluation were done for every case. Informed consents were obtained before inclusion in our study. Participants with any medical condition that may deceive the study results were excluded.

\subsection{Blood sampling}

After overnight fasting for (12 hours), samples $(7-10 \mathrm{ml})$ of morning blood were collected. Separate collection of samples was done as follows: one whole blood sample (3 $\mathrm{ml}$ ) with disodium-ethlenediamine tetra-acetic acid (EDTA) for DNA extraction. Another one was directed to serum collection aliquots to measure fasting insulin, lipid profile, ALT $\&$ AST. The last one was fluoride containing to collect plasma for fasting plasma glucose measuring. Lipid profile and plasma glucose rates were checked instantly; while, we froze other samples were instantly at $\left(-\right.$ Eighty $\left.{ }^{\circ} \mathrm{C}\right)$ till sequent tests were performed.

\subsection{Anthropometric and biochemical measurements}

Body Mass Index (BMI) and Waist Circumference (WC) represented the anthropometric measurements.

Plasma glucose which was checked using automated biochemistry analyzer - Dimension RxL analyzer (Dade Behring, Newark, DE). Autoanalyser (Beckman synchron cx systems) was used for measuring aspartate aminotransferase (AST) and alanine aminotransferase (ALT), serum total cholesterol (TC), triacylglycerol (TAG) and high- density lipoprotein (HDL) cholesterol, while, Friedewald formula was used for Lowdensity lipoprotein (LDL) calculation [15]. ELISA kit (Immunospec $₫$ kit, provided from Immunospec Corporation, Canoga Park, CA, USA) was used for measuring serum insulin. Insulin resistance was measured using Homeostasis model assessment (HOMA-IR) calculation: [(FBG X fasting insulin)/405] [16] and Quantitative insulin sensitivity check index (QUICKI) - calcualtion: 1/[log FI $(\mu \mathrm{IU} / \mathrm{ml})+\log$ FBG $(\mathrm{mg} / \mathrm{dl})]$ [17]. All these represented the Biochemical measurements. 


\subsection{Genotyping}

QIAamp DNA Mini Kit protocol (QIAGEN, Santa Clarita, CA) was used for DNA extraction. Then, extracted DNA was stored at $-80{ }^{\circ} \mathrm{C}$ until used for genotyping assay. TaqMan SNP Genotyping Assays (ABI; Applied Biosystems international, Foster City, CA) using Real-Time PCR System (The Applied Biosystems ${ }^{\circledR}$ Step One PlusTM) was used for performing FTO gene genotyping rs9939609 (A < T). To assure genotyping reproducibility, $20 \%$ selections of the samples were re-genotyped with $100 \%$ concordance.

\subsection{Statistical analysis}

Data were analyzed using the IBM SPSS for Mac version 23. Numeric variables were expressed as (Mean \pm SD), numeric nonparametric variables as (median and range), and categorical variables as (number and percentage).

Independent Student's t-test (numeric parametric variables) and Mann-Whitney's Utest (numeric non-parametric variables) were used for analysis of difference between the two groups. While the one-way analysis of variance (ANOVA) was used for comparisons between the three groups with respect to normally distributed numeric variables. We used Bonforreni post hoc for the pair compare for significant tests. We used Bonforreni post hoc and The Kruskal- Wallis tests for groups' comparison concerning numeric variables with abnormal distribution. We used Chisquare test for groups comparison concerning categorical data. We applied Conservative Bonferroni adjustment for considerable tests (High-density lipoprotein cholesterol and Alanine aminotransferase) to avert multiple testing error (adjusted $P$ value at 0.01 ).

We compared allele frequency and Genotype distributions with the $(\chi 2)$ test and computed Hardy-Weinberg equilibrium by online calculator. We performed Logistic regression for evaluation of associations of rs 9,939,609 single-nucleotide polymorphism with severity of COVID-19 (odds ratio was calculated as well as their adjusted values for age with their ninety fifth percentile confidence interval and congruent $p$-value). We used multiple regression models to study FTO polymorphism association with levels of alanine aminotransferase after correction of serum triglycerides and body mass index.

\section{RESULTS}

'Table 1', shows a considerable difference in both biochemical and anthropometric measurements among our study groups. Fasting plasma glucose (FPG), serum triacylglycerols (TAG), total cholesterol (TC), low-density lipoprotein cholesterol (LDL-C), body mass index (BMI) and waist circumference (WC) were significantly higher, while high-density lipoprotein cholesterol (HDL-C) level was lower in the severe COVID-19 group versus mild and moderate groups.

As shown in 'Table 2'. In the whole studied group, the distribution of genotype for rs 9,939,609 variant was $52.8 \%$ TA, $34 \%$ TT, and $13.2 \%$ AA. Severe group versus mild group genotype distribution was $54.2 \%$ TA, $24.1 \%$ TT, and $21.7 \%$ AA versus $53.4 \%$ TA, $42 \%$ TT, and $4.6 \%$ AA successively.

As depicted in 'Table 2', the association of genotype distribution with COVID-19 severity was significant $(\chi 2=8.6 / \mathrm{P}=0.014)$, the dominant genetic model was increased by 1.86 fold in the odds of severe COVID-19 cases $(95 \%$ C.I $=1.08-3.4, p=0.029)$. The AA genotype was increased by 2.95 -fold in the odds of severe COVID-19 cases (95\% C.I $=1.23$ $6.42, \mathrm{p}=0.017)$ regarding recessive genetic model.

For high-density lipoprotein cholesterol (HDLC) levels and Alanine aminotransferase (ALT), we found no significant difference in biochemical and anthropometric measurements of studied sample at all models (dominant, additive, \& recessive) among different genotypes. as regards to high density lipoprotein cholesterol (HDL-C), significant lower $(\mathrm{P}=0.009)$ levels of AA genotype were shown and it was interesting that levels persisted significant after conservative Bonferroni adjustment. As regards to Alanine aminotransferase (ALT), significant higher $(\mathrm{P}=$ 0.02 ) levels of AA carriers were shown, as mentioned in 'Table 3'. After correction of serum TAG and BMI the significant association remained, but after using the conservative Bonferroni adjustment for multiple testing this association was eliminated. 
Table 1 Characteristics of severe cases $(n=124)$, and mild cases $(n=129)$

\begin{tabular}{|c|c|c|c|}
\hline & $\begin{array}{c}\text { Group I } \\
\text { Severe cases } \\
(\mathrm{N}=124)\end{array}$ & $\begin{array}{l}\text { Group II } \\
\text { Mild cases } \\
(\mathrm{N}=129) \\
\end{array}$ & $\mathrm{P}$ \\
\hline Age, years, mean \pm S.D. Dép & $51.8 \pm 16.4$ & $38.5 \pm 14.9$ & $0.130^{\mathrm{c}}$ \\
\hline BMI, $\mathrm{Kg} / \mathrm{m}^{2}$, mean \pm S.D & $37.64 \pm 5.4$ & $24.64 \pm 5.3$ & $<0.001^{\mathrm{a}}$ \\
\hline is & $119.66 \pm 10.66$ & $78.66 \pm 9.2$ & $<0.001^{\mathrm{a}}$ \\
\hline TC (mg/dl), mean \pm S.D. D. & $182.11 \pm 44.51$ & $140.01 \pm 34.21$ & $<0.001^{\mathrm{a}}$ \\
\hline TAG $(\mathrm{mg} / \mathrm{dl})$, mean \pm S.D & $176.44 \pm 84.16$ & $140.44 \pm 44.13$ & $<0.001^{\mathrm{a}}$ \\
\hline HDL-C $(\mathrm{mg} / \mathrm{dl})$, mean \pm S.D & $38.51 \pm 9.32$ & $44.76 \pm 8.07$ & $<0.001^{\mathrm{a}}$ \\
\hline LDL-C (mg/dl), mean \pm S.D & $107.11 \pm 38.44$ & $98.48 \pm 18.32$ & $0.034^{\mathrm{a}}$ \\
\hline FPG (mg/dl), median (min-max) & $161(64-361)$ & $89(60-323)$ & $<0.001^{b}$ \\
\hline FSI $(\mu \mathrm{IU} / \mathrm{mL})$, median $(\min -\max )$ & $13.29(2.9-30.2)$ & $8.5(1-28)$ & $<0.001^{b}$ \\
\hline HOMA-IR, median (min-max) & $4.58(0.67-20.44)$ & $1.9(0.2-23.82)$ & $<0.001^{b}$ \\
\hline QUICKI, mean \pm S.D & $0.31 \pm 0.14$ & $0.35 \pm 0.05$ & $<0.001^{\mathrm{a}}$ \\
\hline $\begin{array}{l}\text { FTO (rs9939609) } \\
\text { TT, n(\%) } \\
\text { AT, n(\%) } \\
\text { AA, n(\%) }\end{array}$ & $\begin{array}{l}24(24.1) \\
49(54.2) \\
19(21.7)\end{array}$ & $\begin{array}{c}43(42) \\
54(53.4) \\
8(4.6)\end{array}$ & $0.014^{\mathrm{c}}$ \\
\hline
\end{tabular}

Values are mean \pm SD for parametric variables or median (range) for non-parametric variables.

${ }^{\mathrm{a}}$ Independent T- test, ${ }^{\mathrm{b}}$ Mann-Whitney U test, ${ }^{\mathrm{c}}$ Chi-square test, all with (two-sided $\mathrm{p}$ value $>0.05$ non-significant)

Table 2 Fat mass and obesity gene (FTO) genotypes and COVID-19 severity association

\begin{tabular}{|l|c|c|c|}
\hline & OR & $\mathbf{9 5 \%} \mathbf{C I}$ & $\mathbf{P}$ \\
\hline $\begin{array}{l}\text { Dominant Genetic Model } \\
\text { TT }\end{array}$ & Reference & Reference \\
\hline AT/AA & 1.86 & $1.08,3.4$ & \\
& & & 0.029 \\
\hline $\begin{array}{l}\text { Recessive Genetic Model } \\
\text { AT/TT }\end{array}$ & Reference & Reference \\
\hline AA & 2.95 & $1.23,6.42$ & \\
& & & 0.017 \\
\hline
\end{tabular}

Logistic regression employed for calculation of ${ }^{\mathrm{a}}$ ORs, 95\% CIs, and $\mathrm{p}$ values. 
Table 3 Fat mass and obesity (rs9939609) polymorphism association with patients' clinical characteristics and biochemical measures

\begin{tabular}{|c|c|c|c|c|}
\hline \multirow[t]{2}{*}{ Characteristics } & \multicolumn{3}{|c|}{ FTO (rs9939609) Genotypes } & \multirow[t]{2}{*}{$\mathrm{P}$} \\
\hline & $\mathrm{TT}(\mathrm{n}=87)$ & $\operatorname{AT}(n=114)$ & $\mathrm{AA}(\mathrm{n}=52)$ & \\
\hline Age, years, mean \pm S.D. D. & $42.3 \pm 7.6$ & $44.12 \pm 9.7$ & $44.5 \pm 9.6$ & $0.27^{\mathrm{a}}$ \\
\hline BMI, $\mathrm{Kg} / \mathrm{m}^{2}$, mean \pm S.D & $32 \pm 5$ & $30.36 \pm 7.1$ & $32.1 \pm 7.3$ & $0.52^{\mathrm{a}}$ \\
\hline 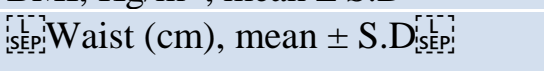 & $101.2 \pm 20.1$ & $102.3 \pm 19.1$ & $105.8 \pm 15.1$ & $0.67^{\mathrm{a}}$ \\
\hline TC (mg/dl), mean \pm S.D. Diseppi & $176.3 \pm 32.1$ & $162.3 \pm 34.3$ & $153.4 \pm 39$ & $0.19^{\mathrm{a}}$ \\
\hline TAG $(\mathrm{mg} / \mathrm{dl})$, mean \pm S.D & $147.3 \pm 53.6$ & $128.5 \pm 71.8$ & $126 \pm 57$ & $0.52^{\mathrm{a}}$ \\
\hline HDL-C (mg/dl), mean \pm S.D & $43.2 \pm 9.3$ & $41.3 \pm 7$ & $38 \pm 8.3$ & $0.01^{\mathrm{a}}$ \\
\hline LDL-C (mg/dl), mean \pm S.D & $104.4 \pm 29.6$ & $101.4 \pm 31.6$ & $98.1 \pm 26.7$ & $0.77^{\mathrm{a}}$ \\
\hline FPG (mg/dl), median (min-max) & $105(67-313)$ & $99.5(62-363)$ & 137(76-340) & $0.21^{\mathrm{b}}$ \\
\hline FSI $(\mu \mathrm{IU} / \mathrm{mL})$, median $(\min -\max )$ & $9.5(2.4-28)$ & $9.3(1-29.1)$ & $11(2.9-29.2)$ & $0.56^{\mathrm{b}}$ \\
\hline HOMA-IR, median (min-max) & $3.1(0.7-23.8)$ & $2(0.2-21.5)$ & $3.6(1.9-20.6)$ & $0.29^{b}$ \\
\hline QUICKI, mean \pm S.D & $0.23 \pm 0.032$ & $0.33 \pm 0.08$ & $0.31 \pm 0.024$ & $0.11^{\mathrm{a}}$ \\
\hline AST (IU/mL), median (min-max) & $14(4-52)$ & $12.4(4-62)$ & $17(8-48)$ & $0.18^{b}$ \\
\hline ALT (IU/mL), median (min-max) & $16(4-59)$ & $12(4-56)$ & $14.5(7-48)$ & $0.02^{b}$ \\
\hline
\end{tabular}

ALT alanine aminotransferase, AST aspartate amino-transferase, BMI Body mass index, FPG

Fasting plasma glucose, FSI Fasting serum insulin, sEpPDL-C High-density lipoprotein-cholesterol, LDL-C Low-density lipoprotein-cholesterol, TAG Triacylglycerol, TC Total cholesterol, WC Waist circumference

aOne-way ANOVA, ${ }^{b}$ Kruskal-Wallis, all with (two-sided $\mathrm{p}$ value $>0.05$ non-significant)

\section{DISCUSSION}

Our study is the first one designed for investigation of fat mass and obesity gene (FTO) rs9939609 genotype distribution and its association with COVID-19 severity.

Obesity effect on COVID-19 severity was declared in many studies. Busetto et al. found that patients with overweight and obesity admitted in a medical ward for severe acute respiratory syndrome coronavirus 2-related pneumonia, despite their younger age, required more frequently assisted ventilation and access to intensive or semi-intensive care units than normal weight patients [19]. Gao et al. concluded that obese patients had increased odds of progressing to severe COVID-19 [12].
AA genotype subjects have higher body mass index and waist circumference in comparison to TA and TT subjects, yet this wasn't statistically significant. This may be related to comparatively small sample size and different effect size in case of body mass index. This is in agreed with 3 former studies that didn't find association of rs9939609 FTO polymorphism with body mass index and/or waist circumference in a small sample size as well [20-22]. Xu et al. found that under recessive model, some metabolic parameters were significantly associated with FTO variations [23]. We assumed that under recessive model, the manifested association in this current study might result from the associated (AA) subjects lowered high-density lipoprotein cholesterol (HDL-C) levels compared to (TT). 
Those differences may be due to different age, sample size, ethnic group and/or study design.

The Fat mass and obesity gene association with COVID-19 severity may be related to other associated comorbidities such as type 2 diabetes mellitus and obesity [24] in addition to abnormalities of serum lipid [21, 25]. FTO protein linkage to obesity and type 2 diabetes mellitus (T2DM) exact mechanism is still unknown.

Fat mass and obesity (FTO) gene plays an important role in energy homeostasis as it is expressed (highly) in the hypothalamus, [26]. Fat mass and obesity (FTO) gene genetic variants were associated with increased energy intake [22, 27, 28]. According to in vitro studies and bioinformatics FTO encodes for demethylase enzyme for deoxyribonucleic acid and (especially) single strands of Ribonucleic acid nucleotides [26, 29]. There is significant association between DNA methylation state changes and many different diseases and health conditions including obesity [30, 31]. For instance, interestingly folate and vitamin B12 maternal levels affected Indian children obesity proving the important association of methylation state in obesity and other disorders [32,33]. DNA methylation epigenetic changes might mediate fat mass and obesity gene linkage with obesity [34]. Furthermore, this gene has a key role in food intake regulation via its effect on hypothalamus and sensing amino acids levels [35]. It was also proved that FTO gene genetic variants are linked to another gene named IRX3; which may explain FTO single nucleotide polymorphisms with type 2 diabetes mellitus and obesity [36]. Wu et al. assumed that the expression of Fat mass and obesity gene was affected by intronic genetic variants like rs9939609, that might alter adipose tissue adipogenesis [37]. Rat model studies with NAFLD (nonalcoholic fatty liver disease) interestingly found that there was increased lipogenesis and oxidative stress when there was overexpression of FTO in liver as well as increased alanine aminotransferase levels [38]. Guan et al. showed that obesity susceptible genes variants were significantly associated with ALT levels, but not fat mass and obesity, dependent or independent of body mass index [39].

We hope that our concluded results will be a beginning for future studies putting on consideration larger sample size.

\section{CONCLUSIONS}

Our current study investigated for the first time a probable linkage between the fat mass and obesity gene homozygous variant (AA) and the COVID-19 severity in Egyptian patients which may be mediated through high density lipoprotein cholesterol lowered levels as well as the probable role of polymorphism in the complications of COVID-19

\section{Funding}

None to declare.

\section{Competing interest}

The authors declare that there is no conflict of interests regarding this study.

\section{REFERENCES}

1. Zhou P, Yang XL, Wang XG, Hu B, Zhang L, Zhang W, Si HR, Zhu Y, Li B, Huang CL, Chen HD. A pneumonia outbreak associated with a new coronavirus of probable bat origin. nature. 2020 Mar;579(7798):270-3.

2. Turner AJ, Hiscox JA, Hooper NM. ACE2: from vasopeptidase to SARS virus receptor. Trends Pharmacol Sci. 2004 Jun 1;25(6):291-4.

3. Siddiqi HK, Mehra MR. COVID-19 illness in native and immunosuppressed states: a clinicaltherapeutic staging proposal. J Heart Lung Transplant. 2020 May;39(5):405.

4. Guan WJ, Ni ZY, Hu Y, Liang WH, Ou CQ, He JX, Liu L, Shan H, Lei CL, Hui DS, Du B. Clinical characteristics of coronavirus disease 2019 in China. N Engl J Med. 2020 Apr 30;382(18):170820.

5. Frayling TM, Timpson NJ, Weedon MN, Zeggini E, Freathy RM, Lindgren CM, Perry JRB, Elliott KS, Lango H, Rayner NW, Shields B, Harries LW, Barrett JC, Ellard S, Groves CJ, Knight B, Patch AM, Ness AR, Ebrahim S, Lawlor DA, Ring SM, Ben-Shlomo Y, Jarvelin M-R, Sovio U, Bennett AJ, Melzer D, Ferrucci L, Loos RJF, Barroso I, Wareham NJ, Karpe F, Owen KR, Cardon LR, Walker M, Hitman GA, Palmer CNA, Doney ASF, Morris AD, Smith GD, Consortium TWTCC, Hattersley AT, McCarthy MI. A common variant in the FTO gene is associated with body mass index and predisposes to childhood and adult obesity. Science. 2007;316(5826):889-94. doi: 10.1126/science. 1141634 .

6. Gonzalez-Sanchez JL, Zabena C, Martinez-Larrad MT, Martinez-Calatrava MJ, Perez-Barba M, Serrano-Rios M. Variant rs9939609 in the FTO 
gene is associated with obesity in an adult population from Spain. Clin Endocrinol. 2009;70(3):390-3. doi: 10.1111/j.13652265.2008.03335.x.

7. Sentinelli F, Incani M, Coccia F, Capoccia D, Cambuli VM, Romeo S, Cossu E, Cavallo MG, Leonetti F, Baroni MG. Association of FTO polymorphisms with early age of obesity in obese Italian subjects. Exp Diabetes Res. 2012;2012: 872176. doi: 10.1155/2012/872176.

8. Zhang G, Karns R, Narancic NS, Sun G, Cheng H, Missoni S, Durakovic Z, Rudan P, Chakraborty R, Deka R. Common SNPs in FTO gene are associated with obesity related anthropometric traits in an island population from the eastern Adriatic coast of Croatia. PLoS One. 2010;5(4):e10375. doi: 10.1371/ journal.pone.0010375.

9. Peeters A, Beckers S, Verrijken A, Roevens P, Peeters P, Van Gaal L, Van Hul W. Variants in the FTO gene are associated with common obesity in theBelgian population. Mol Genet Metab. 2008;93(4):481-4. doi: 10.1016/j.ymgme.2007.10.011.

10. Scuteri A, Sanna S, Chen WM, Uda M, Albai G, Strait J, Najjar S, Nagaraja R, SLeperoru M, Usala G, Dei M, Lai S, Maschio A, Busonero F, Mulas A, Ehret GB, Fink AA, Weder AB, Cooper RS, Galan P, Chakravarti A, Schlessinger D, Cao A, Lakatta E, Abecasis GR. Genome-wide association scan shows genetic variants in the FTO gene are associated with obesity-related traits. PLoS Genet. 2007;3(7):e115.

10.1371/journal.pgen.0030115.

11. Khella MS, Hamdy NM, Amin AI, El-Mesallamy HO. The (FTO) gene polymorphism is associated with metabolic syndrome risk in Egyptian females: a case-control study. BMC Med Genet. 2017 Dec;18(1):1-8.

12. Gao F, Zheng KI, Wang XB, Sun QF, Pan KH, Wang TY, Chen YP, Targher G, Byrne CD, George $\mathrm{J}$, Zheng $\mathrm{MH}$. Obesity is a risk factor for greater COVID-19 severity. Diabetes care. 2020 Jul 1;43(7):e72-4.

13. Popkin BM, Du S, Green WD, Beck MA, Algaith T, Herbst CH, Alsukait RF, Alluhidan M, Alazemi $\mathrm{N}$, Shekar M. Individuals with obesity and COVID19: A global perspective on the epidemiology and biological relationships. Obes Rev. 2020 Nov;21(11):e13128.

14. McSharry D, Malhotra A. Potential influences of obstructive sleep apnea and obesity on COVID-19 severity. J Clin Sleep Med. 2020 Sep 15;16(9):1645-.

15. Friedewald WT, Levy RI, Fredrickson DS. Estimation of the concentration of low-density lipoprotein cholesterol in plasma, without use of the preparative ultracentrifuge. Clin Chem. 1972;18(6):499-502.

16. Matthews DR, Hosker JP, Rudenski AS, Naylor BA, Treacher DF, Turner RC. Homeostasis model assessment: insulin resistance and beta-cell function from fasting plasma glucose and insulin concentrations in man. Diabetologia. 1985;28(7):412-9.

17. Katz A, Nambi SS, Mather K, Baron AD, Follmann DA, Sullivan G, Quon MJ. Quantitative insulin sensitivity check index: a simple, accurate method for assessing insulin sensitivity in humans. J Clin Endocrinol Metab. 2000;85(7): 2402-10. doi: 10.1210/jcem.85.7.6661.

18. Rodriguez S, Gaunt TR, Day INM. HardyWeinberg equilibrium testing of biological ascertainment for Mendelian randomization studies. Am J Epidemiol. 2009;169(4):505-14. doi: 10.1093/aje/kwn359.

19. Busetto L, Bettini S, Fabris R, Serra R, Dal Pra C, Maffei P, Rossato M, Fioretto P, Vettor R. Obesity and COVID-19: an Italian snapshot. Obesity. 2020 Sep;28(9):1600-5.

20. Ohashi J, Naka I, Kimura R, Natsuhara K, Yamauchi T, Furusawa T, Nakazawa M, Ataka Y, Patarapotikul J, Nuchnoi P, Tokunaga K, Ishida T, Inaoka T, Matsumura Y, Ohtsuka R. FTO polymorphisms in oceanic populations. J Hum Genet. 2007;52(12):1031-5. doi: 10.1007/s10038007-0198-2.

21. Zabena C, Gonzalez-Sanchez JL, Martinez-Larrad MT, Torres-Garcia A, Alvarez-Fernandez-Represa J, Corbaton-Anchuelo A, Perez-Barba M, SerranoRios M. The FTO obesity gene. Genotyping and gene expression analysis in morbidly obese patients. Obes Surg. 2009;19(1):87-95. doi: 10.1007/s11695- 008-9727-0.

22. Speakman JR, Rance KA, Johnstone AM. Polymorphisms of the FTO gene are associated with variation in energy intake, but not energy expenditure. Obesity (Silver Spring, Md). 2008;16(8):1961-5. doi: 10.1038/oby.2008.318.

23. Xu Y, Ling J, Yang M, Wang H, Zhang S, Zhang X, Zhu Y. Rs7206790 And rs11644943 in FTO gene are associated with risk of obesity in Chinese school-age population. PLoS One. 2014;9(9):e108050. doi: 10.1371/journal. pone.0108050.

24. Hertel JK, Johansson S, Sonestedt E, Jonsson A, Lie RT, Platou CG, Nilsson PM, Rukh G, Midthjell K, Hveem K, Melander O, Groop L, Lyssenko V, Molven A, Orho-Melander M, Njolstad PR. FTO, type 2 diabetes, and weight gain throughout adult life: a meta-analysis of 41,504 subjects from the Scandinavian HUNT, MDC, and MPP studies. Diabetes. 2011;60(5):1637-44. doi: 10.2337/db101340.

25. Al-Attar SA, Pollex RL, Ban MR, Young TK, Bjerregaard P, Anand SS, Yusuf S, Zinman B, Harris SB, Hanley AJ, Connelly PW, Huff MW, Hegele RA. Association between the FTO rs9939609 polymorphism and the metabolic syndrome in a non-Caucasian multi-ethnic sample. Cardiovasc Diabetol. 2008;7:5. doi: 10.1186/14752840-7-5.

26. Gerken T, Girard CA, Tung Y-CL, Webby CJ, Saudek V, Hewitson KS, Yeo GSH, McDonough MA, Cunliffe S, McNeill LA, Galvanovskis J, 
Rorsman P, Robins P, Prieur X, Coll AP, Ma M, Jovanovic Z, Farooqi IS, Sedgwick B, Barroso I, Lindahl T, Ponting CP, Ashcroft FM, O'Rahilly S, Schofield CJ. The obesity-associated FTO gene encodes a 2-Oxoglutarate-dependent nucleic acid demethylase. Science. 2007;318(5855):1469-72. doi: $10.1126 /$ science. 1151710 .

27. Cecil JE, Tavendale R, Watt P, Hetherington MM, Palmer CN. An obesity- associated FTO gene variant and increased energy intake in children. $\mathrm{N}$ Engl J Med. 2008;359(24):2558-66. doi: 10.1056/NEJMoa0803839.

28. Haupt A, Thamer C, Staiger H, Tschritter O, Kirchhoff K, Machicao F, Haring HU, Stefan N, Fritsche A. Variation in the FTO gene influences food intake but not energy expenditure. Exp Clin Endocrinol Diabetes. 2009;117(4):194- 7. doi: 10.1055/s-0028-1087176.

29. Jia G, Yang C-G, Yang S, Jian X, Yi C, Zhou Z, He C. Oxidative demethylation of 3-methylthymine and 3-methyluracil in single-stranded DNA and RNA by mouse and human FTO. FEBS letters. 2008;582(23-24):3313-9. doi: 10.1016/J. Febslet.2008.08.019.

30. Campion J, Milagro FI, Martinez JA. Individuality and epigenetics in obesity. Obesity reviews : an official journal of the International Association for the Study of Obesity. 2009;10(4):383-92. doi: 10.1111/j.1467-789X.2009.00595.x.

31. Javierre BM, Fernandez AF, Richter J, Al-Shahrour F, Martin-Subero JI, Rodriguez-Ubreva J, Berdasco M, Fraga MF, O'Hanlon TP, Rider LG, Jacinto FV, Lopez-Longo FJ, Dopazo J, Forn M, Peinado MA, Carreno L, Sawalha AH, Harley JB, Siebert R, Esteller M, Miller FW, Ballestar E. Changes in the pattern of DNA methylation associate with twin discordance in systemic lupus erythematosus. Genome Res. 2010;20(2):170-9. doi: 10.1101/gr.100289.109.

32. Yajnik CS, Deshpande SS, Jackson AA, Refsum H, Rao S, Fisher DJ, Bhat DS, Naik SS, Coyaji KJ, Joglekar CV, Joshi N, Lubree HG, Deshpande VU, Rege SS, Fall CH. Vitamin B12 and folate concentrations during pregnancy and insulin resistance in the offspring: the Pune maternal nutrition study. Diabetologia. 2008;51(1):29-38. doi: 10.1007/s00125-007-0793-y.

33. Yajnik CS, Janipalli CS, Bhaskar S, Kulkarni SR, Freathy RM, Prakash S, Mani KR, Weedon MN, Kale SD, Deshpande J, Krishnaveni GV, Veena SR, Fall CH, McCarthy MI, Frayling TM, Hattersley AT, Chandak GR. FTO gene variants are strongly associated with type 2 diabetes in south Asian Indians. Diabetologia. 2009;52(2):247-52. doi: 10.1007/s00125-008-1186-6.

34. Han Z, Niu T, Chang J, Lei X, Zhao M, Wang Q, Cheng W, Wang J, Feng Y, Chai J. Crystal structure of the FTO protein reveals basis for its substrate specificity. Nature. 2010;464(7292):1205$209 . \quad$ https://www.nature.com/ nature/journal/v464/n7292/suppinfo/nature08921.ht $\mathrm{ml}$.

35. Gulati P, Yeo GS. The biology of FTO: from nucleic acid demethylase to amino acid sensor. Diabetologia. 2013;56(10):2113-21. doi: 10.1007/s00125- 013-2999-5.

36. Smemo S, Tena JJ, Kim K-H, Gamazon ER, Sakabe NJ, Gomez-Marin C, Aneas I, Credidio FL, Sobreira DR, Wasserman NF, Lee JH, Puviindran V, Tam D, Shen M, Son JE, Vakili NA, Sung H-K, Naranjo S, Acemel RD, Manzanares M, Nagy A, Cox NJ, Hui C-C, Gomez-Skarmeta JL, Nobrega MA. Obesity- associated variants within FTO form long-range functional connections with IRX3. Nature. 2014;507(7492):371-5. doi: 10.1038/nature13138.

37. Wu Q, Saunders RA, Szkudlarek-Mikho M, Idl S, Chin K-V. The obesity- associated Fto gene is a transcriptional coactivator. Biochem Biophys Res Commun. 2010;401(3):390-5. doi: 10.1016/j. bbrc.2010.09.064.

38. Guo J, Ren W, Li A, Ding Y, Guo W, Su D, Hu C, $\mathrm{Xu}$ K, Chen H, Xu X, Yang T, Jia W. Fat mass and obesity-associated gene enhances oxidative stress and lipogenesis in nonalcoholic fatty liver disease. Dig Dis Sci. 2013;58(4):1004-9. doi: 10.1007/s10620-012-2516-6.

39. Guan L, Shang XR, Liu FH, Song JY, Ma J, Wang HJ. Association of INSIG2 rs9308762 with ALT level independent of BMI. J Pediatr Gastroenterol Nutr. 2014;58(2):155-9. doi: 10.1097/MPG.0b013e3182a87b71.

\section{HOW TO CITE}

Sarhan, W., Ismail, N., Zidan, N., El-Hawary, A., Makani, V., Abd elnour, H. Association of Fat mass and obesity gene (FTO) polymorphism with COVID-19 severity in Egyptian obese patients. Zagazig University Medical Journal, 2021; (984-991): -. doi: 10.21608/zumj.2021.80189.2260 